\title{
Dietary supplementation with autochthonous Bacillus cereus improves growth performance and survival in tambaqui Colossoma macropomum
}

\author{
Joel A R Dias ${ }^{1}$ (D) | Higo A Abe ${ }^{1}$ (D) | Natalino C Sousa ${ }^{1}$ | Márcia V S Couto ${ }^{1}$ | Carlos \\ A M Cordeiro $^{1}$ | Juliana O Meneses ${ }^{2}$ | Fernanda S Cunha ${ }^{2}$ (D) | Jose Luiz P Mouriño ${ }^{3}$ | \\ Mauricio L Martins ${ }^{3}$ (D) | Luís A L Barbas ${ }^{4}$ | Paulo C F Carneiro ${ }^{5}$ | Alexandre N Maria ${ }^{5}$ | \\ Rodrigo Y Fujimoto ${ }^{5}$
}

${ }^{1}$ Federal University of Pará (UFPA) Castanhal, PA, Brazil

${ }^{2}$ Tiradentes University (UNIT), Farolândia, Aracaju, SE, Brazil

${ }^{3}$ Aquatic Organisms Health Laboratory (AQUOS), Federal University of Santa Catarina (UFSC), Florianópolis, SC, Brazil

${ }^{4}$ Tropical Species Aquaculture Laboratory (LAET), Federal Institute of Education, Science and Technology of Pará (IFPACastanhal), Castanhal, PA, Brazil

${ }^{5}$ Brazilian Agricultural Research Corporation - EMBRAPA Tabuleiros Costeiros, Aracaju, SE, Brazil

\section{Correspondence}

Rodrigo Yudi Fujimoto, Empresa Brasileira de Pesquisa Agropecuária (Embrapa Tabuleiros Costeiros), Avenida Beira Mar 3250, Bairro Jardins, CEP 49025-040, Aracaju, SE, Brazil.

Email: ryfujim@hotmail.com

Funding information

Conselho Nacional de Desenvolvimento Científico e Tecnológico, Grant/Award Number: 432622/2016-0; CNPq, Grant/ Award Number: 305869, 2014-0

\begin{abstract}
The aim of this study was to evaluate the effect of dietary supplementation with the autochthonous probiotic bacteria Bacillus cereus on growth performance, haematological parameters and survival of tambaqui (Colossoma macropomum). Tambaqui fingerlings $(0.94 \pm 0.02 \mathrm{~g}$ ) were fed for 120 days the following diets: basal (without probiotic) and three supplemented diets $\left(4.2 \times 10^{4}, 3.9 \times 10^{6}\right.$ and $3.3 \times 10^{8} \mathrm{CFU} /$ g). Growth performance and haematological parameters were evaluated every 30 days. Thereafter, fish were challenged against Aeromonas hydrophila and survival was evaluated. Probiotic B. cereus improved weight and length gains $(p<0.05)$, and increased neutrophils and thrombocyte counts $(p<0.05)$ in tambaqui supplemented with $3.9 \times 10^{6} \mathrm{CFU} / \mathrm{g}$ diet. Challenged fish fed unsupplemented diet presented the lowest survival rate (33.4\%) while fish fed diets supplemented at $4.2 \times 10^{4}$, $3.9 \times 10^{6}$ and $3.3 \times 10^{8} \mathrm{CFU} / \mathrm{g}$ B. cereus had $88.8 \%, 80.5 \%$ and $80.5 \%$ relative per cent survival respectively. These results demonstrated that $B$. cereus supplemented as probiotics to $C$. macropomum for 120 days improved physiological and haematological responses, leading to enhanced survival in this fish species.
\end{abstract}

KEYWORDS

amazon, bacterium, fish, haematology, nutrition, performance

\section{1 | INTRODUCTION}

The tambaqui Colossoma macropomum (Cuvier, 1818) is an Amazon fish species of great economic importance to South America, mainly in Brazil. This fish is produced under intensive aquaculture systems, easily spawning after hormonal induction, presenting fast growth, and good tolerance to high temperatures and low levels of dissolved oxygen (Morais \& O'Sullivan, 2017; Sales \& Maia, 2013).

Under intensive rearing systems, confined fish are constantly exposed to acute or chronic stress as a consequence of handling, poor water quality and overcrowding. Such conditions can affect homeostasis, leading to impaired immune responses (Hoseinifar, 
Sun, \& Caipang, 2016; Madani, Adorian, Farsani, \& Hoseinifar, 2018; Nawaz, Javaid, Irshad, Hoseinifar, \& Xiong, 2018), being commonly observed during the early life stage of fish, particularly in larvae and juveniles. Furthermore, such stressors increase the susceptibility of fish to diseases. In this regard, many farmers have used antibiotics in an indiscriminate manner, as a prophylactic measure, which can result in adverse effects including pathogen resistance and environmental contamination (Doan et al., 2018; Jatobá \& Mouriño, 2015).

Recently, new strategies have emerged as alternatives for disease prevention and improved performance in aquaculture. Among these, probiotics have received great attention, as they can be administered by enrichment of live feed, as additives to the diet, or simply added to the maintenance water (Araújo et al., 2017; Doan et al., 2018; Nawaz et al., 2018).

The most commonly used probiotics in fish farming belong to bacteria of the genus Bacillus (Gatesoupe, 1999; Wang, Tian, Yao, \& $\mathrm{Li}, 2008$ ); however, contradictory results have been reported on the beneficial effects of these bacteria on growth performance and immunological resistance in tambaqui fed such probiotic-supplemented diets (Ferreira et al., 2014; Azevedo et al., 2016 and Paixão et al., 2017), The probiotics used for tambaqui in previous studies (B. subtilis and $B$. spp.) were commercially developed and not host-associated (Azevedo et al., 2016; Paixão et al., 2017). The isolation and development of host-associated probiotics is recommended as autochthonous bacteria are more persistent in the intestines and could be more effective than other commercial not host-associated probiotics (Doan et al., 2018; Ridha \& Azad, 2016).

In this sense, the objective of the present study was to evaluate the effect of Bacillus cereus, an autochthonous probiotic bacteria isolated from the gut of tambaqui, on growth performance, productivity, haematological parameters and survival of tambaqui Colossoma macropomum juveniles.

\section{2 | MATERIALS AND METHODS}

\section{1 | Experimental fish and rearing conditions}

The experiments were conducted at the Aquaculture Laboratory of Embrapa Tabuleiros Costeiros, Aracaju-SE. Twenty 150-L tanks were used, arranged in a recirculation aquaculture system (RAS) with biological filtration and ultraviolet light. A total of 400 tambaqui (Colossoma macropomum) juveniles $(0.94 \pm 0.02 \mathrm{~g}$, total weight and $49.71 \pm 0.85 \mathrm{~mm}$, total length) were used. Tambaqui were randomly distributed at a density of 20 individuals per tank, corresponding to an initial biomass of $19.7 \pm 0.6 \mathrm{~g}$. All fish were fed the basal diet during the acclimation period. The water quality parameters, temperature $\left(26.12 \pm 2.6^{\circ} \mathrm{C}\right.$ YSI $60, \mathrm{OH}$, USA), $\mathrm{pH}$ $(5.8 \pm 0.9$ YSI $60, \mathrm{OH}$, USA), dissolved oxygen $(6.8 \pm 1.1 \mathrm{mg} / \mathrm{L} \mathrm{YSI}$ 550A, OH, USA), electrical conductivity $(214.2 \pm 4.2 \mu \mathrm{S} / \mathrm{cm}$ YSI 30, $\mathrm{OH}, \mathrm{USA})$ and total ammonia (0.52 $\pm 0.02 \mathrm{mg} / \mathrm{L}$ Hanna HI 93715 Villafranca, Italy) were measured every other day during the experimental period.
The experimental procedures were approved by the Animal Ethics Committee of Embrapa Tabuleiros Costeiros (Protocol \# 29022016.0003).

\section{2 | Bacterial strain}

The Bacillus cereus probiotic strain used in the experiments was initially isolated from the gut of juvenile tambaqui following standard gut microbial isolation procedures followed Ramirez, Cifonni, Pancheniak, and Soccol (2006) and Jatobá et al. (2008). To confirm the bacteria species, the genetic material of purified isolate was extracted for molecular analysis according to the methodology of Sambrook Fritsch and Maniatis (1989), adapted by Jin (2006). The material was quantified (Sambrook \& Russell, 2001) and the isolated region was amplified via polymerase chain reaction (PCR) using the initiators pheS-21- $F \quad\left(5^{\prime}\right.$ CAYCCNGCHCGYGAYATGC 3') and pheS-23-R (5' GGRTGRACCATVCCNGCHCC $3^{\prime}$ ) (Naser et al., 2007). The result of PCR was sequenced by capillary electrophoresis with an $A B I 3730$ Sequencing Analyzer (Applied Biosystems, Forster City, CA, USA). The resulting sequences were compared with the Gene Bank reference.

\subsection{Experimental design and diet preparation}

The experimental design was completely randomized with four treatments (three experimental probiotic-supplemented diets and one probiotic-free diet used as basal or control diet) and five replicates. Commercial diet $(32 \%$ crude protein, $13 \%$ moisture, $4 \%$ ether extract, 7\% fibre; Purina, Brazil) was used as the basal feed. In treatment one, the feed was impregnated with the autochthonous Bacillus cereus bacteria at a concentration of $4.2 \times 10^{4} \mathrm{CFU} / \mathrm{g}$ diet. In treatments two and three, the feed was impregnated with the same bacteria at the concentrations of $3.9 \times 10^{6}$ and $3.3 \times 10^{8} \mathrm{CFU} / \mathrm{g}$ diet, respectively.

The fish were fed daily for 120 days with an initial feeding rate of $8 \%$ of the biomass per tank (Paixão et al., 2017), and adjusted according to monthly biometric measurements, fish appetite and water temperature.

For the preparation of the experimental diets, probiotic strains of $B$. cereus were grown in liquid culture medium (Man, Rogosa, and Sharpe; MRS) at $35^{\circ} \mathrm{C}$ up to the concentration of $3.8 \times 10^{9} \mathrm{CFU} / \mathrm{mL}$. To achieve accurate final concentrations in the diet, the bacterial suspension was diluted in the same culture medium until reaching the concentrations tested in the experiment. After dilution, bacterial suspension was slowly added to the commercial diet with gradual mixing in a laminar airflow chamber under sterilized conditions, according to the methodology of Jatobá et al. (2008). The diet was oven-dried at $35^{\circ} \mathrm{C}$ and stored at $6-10^{\circ} \mathrm{C}$ until use. To ensure high probiotic levels in the supplemented feed, fresh diets were prepared every 7 days.

The evaluation of the probiotic concentration added to the feed was carried out weekly. One gram of each experimental diet was 
macerated in sterile saline solution at $0.65 \%$ and subjected to serial dilutions (1:10). The bacterial suspensions were counted using the spread plate method (Jatobá \& Mouriño, 2015).

\section{4 | Growth performance and haematological parameters}

To assess the performance of the tambaqui juveniles, sampling was carried out every 30 days, and the following variables were analysed: weight gain $(W G)=$ final weight - initial weight; specific growth rate $(S G R)=100 \times($ In final weight - In initial weight time/interval); Fulton's condition factor $(K)=W \times L^{-3}$, where $W=$ fish weight; $L=$ total length (Ricker, 1975); feed conversion ratio $(F C R)=$ total feed consumption $\times$ weight gain of fish $^{-1}$; survival rate $(S)=($ final fish number $\times$ initial fish number $\left.{ }^{-1}\right) \times 100$.

At the end of the feeding trial (120 days), 10 fish from each treatment were randomly selected for blood collection and evaluation of haematological parameters. The animals were anesthetized with eugenol $(60 \mathrm{mg} / \mathrm{L})$ and $1 \mathrm{ml}$ of blood was collected by caudal puncture. Immediately after blood collection, glucose values were evaluated with an automatic metre, AccuCheck Active (Roche Diagnostics, Mannheim, Germany). Leucocyte counts were performed by the method of blood extension, stained with haematological panotic dye, NewProv (Fontes et al., 2014). The total count of red blood cells (cell $\times 10^{6} \mu \mathrm{l}^{-1}$ ) was performed in a Neubauer chamber according to Tavares-Dias and Moraes (2004). Haematocrit analysis was performed according to the methodology described by Goldenfarb, Bowyer, Hall, and Brosius (1971). The measurement of total plasma protein was performed by means of a portable refracto metre, RHC-200ATC (Huake Instrument Co., Ningbo, China), and the evaluation of haemoglobin concentrations was performed in a biochemical Thermo Plate analyser (Thermoplate, São Paulo, Brazil) according to Kamper and Zijlstra (1961). From these data, the following haematimetric indices were calculated: mean corpuscular volume (MCV: $\left.\mathrm{Ht} \times 10 \mathrm{er}^{-1}\right)$, mean corpuscular haemoglobin $(\mathrm{MCH}: \mathrm{Hb} \times 10$ $\mathrm{er}^{-1}$ ) and mean corpuscular haemoglobin concentration (MCHC: $\mathrm{Hb} \times$ $100 \mathrm{Ht}^{-1}$ ) (Tavares-Dias \& Moraes, 2006; Vallada, 1999).

\section{5 | Bacterial count in the gut}

The evaluation of probiotic colonization in the animal's digestive system was performed at the end of the trial period in accordance with the methodology of Jatobá et al. (2008) and Jatobá and Mouriño (2015). Ten individuals from each treatment were anesthetized with eugenol $(60 \mathrm{mg} / \mathrm{L})$ and killed by section of the spinal cord, followed by the sampling of $1 \mathrm{~g}$ intestinal tissue (anterior and middle sections). The intestine samples were crushed in sterile saline solution $0.65 \%$, followed by serial dilutions (1:10), and plated on MRS agar and TSA agar (Tryptone soy agar), culture medium and nonselective culture medium to evaluate the growth of probiotic and total heterotrophic bacteria, respectively. These plates were incubated at $35^{\circ} \mathrm{C}$ for $48 \mathrm{hr}$, and the cell count was determined in CFU/g of fish gut, according to the methodology of Jatobá et al. (2008).

\subsection{Challenge assay}

After the dietary supplementation period, fish were challenged against $A$. hydrophila and the $\mathrm{LD}_{50}$ was previously determined as $2.7 \times 10^{6} \mathrm{CFU} / \mathrm{g}$. Seventy-five fish were distributed in fifteen $60-\mathrm{L}$ tanks (five fish per tank) in the following groups with three replicates: $3.8 \times 10^{4}, 3.8 \times 10^{6}$ and $3.8 \times 10^{8} \mathrm{CFU} / \mathrm{g}$ B. cereus. There were two control groups, a negative control with unsupplemented fish not injected with $A$. hydrophila and a positive control constituted by unsupplemented fish challenged with the $\mathrm{LD}_{50} A$. hydrophila. Fish were observed every $4 \mathrm{hr}$ for a period of $96 \mathrm{hr}$ to check any behavioural changes and clinical signs of body darkness, lethargy, exophthalmia, haemorrhages and ulcers on the body surface (Pavanelli, Eiras \& Takemoto, 2002). During the challenge period, the survival was determined and moribund fish samples were collected to confirm the bacterial infection and Kock postulate.

Infection intensity was classified as 0-5 according to Ray (1954) protocol: $0=$ no alterations, 1 (Light) = behavioural changes as lethargy and loss of equilibrium, 2 (Light to moderate) = depigmentation and fin erosion, 3 (Moderate) = exophthalmia, haemorrhages on the body surface, ascites and inflammation on the genital pore, 4 (Moderate to strong) = ulcers, altered kidney, liver, spleen and gall bladder, and 5 (Strong) = mortality. The relative per cent survival (RPS) was determined according to Mello et al. (2013) where: [1 - (\% mortality of the supplemented group $\times \%$ mortality in the control group $\left.\left.^{-1}\right)\right] \times 100$.

The water quality was monitored daily at 9 a.m. and 5 p.m. Temperature and dissolved oxygen were measured using a HI9147 device $\left(\right.$ Hanna $\left.^{\circledR}\right)$; electric conductivity and $\mathrm{pH}$ were measured with YSI30 and AKROM2O devices, respectively.

\section{7 | Statistical analysis}

Microbiological counts were log-transformed $(x+1)$ before being subjected to statistical analysis. The results of performance and haematology were investigated for homoscedasticity (Bartlett test) and normality (Shapiro-wilk test) and then subjected to analysis of variance (ANOVA). Survival and relative per cent survival were arsine-transformed prior to being submitted to ANOVA. Tukey's test was used for pair-wise comparison of means. The minimum significance level was set at $5 \%(p<0.05)$ in all cases and the Assistat 7.7 statistical software was used for analyses.

\section{RESULTS}

\subsection{Performance and haematological parameters}

The beneficial effects of the probiotics were first observed after 60 days of feeding, with significant increases in weight gain and productivity, compared with the control (Table 1). The other performance parameters remained unchanged during this period. After 90 days of feeding, the probiotic-supplemented diet, mainly at the higher concentration $\left(10^{8} \mathrm{CFU} / \mathrm{g}\right.$ diet), produced higher total and 
standard length gain, height and weight gain, specific growth rate and productivity, as compared with the control. After 120 days of feeding, enhanced growth performance and productivity of juveniles fed probiotic-supplemented diets was observed; values remained significantly higher than the control group. No differences were observed among treatments regarding condition factor, feed conversion ratio, and survival $(p>0.05)$.

Assessment of erythrocyte count showed that fish fed the probiotic-supplemented diet had increased red cell count compared with the controls (Table 2). At the highest probiotic concentration ( $10^{8} \mathrm{CFU} / \mathrm{g}$ diet), haematocrit and total plasma protein values were significantly higher than those observed in other treatments.

The number of thrombocytes was higher $(p<0.05)$ in the treatment supplemented with $10^{6} \mathrm{CFU} / \mathrm{g}$ diet, as compared with the other treatments and the control group. Supplementation with probiotics did not significantly alter the number of leucocytes, lymphocytes, monocytes or basophils in blood. However, the number of neutrophils increased significantly and linearly with increasing concentration of probiotics in the feed.

\subsection{Bacterial count in the feed and gut}

The concentration of $B$. cereus strain added to the feed kept unchanged during the 7 days of storage $\left(4.2 \times 10^{4}, 3.9 \times 10^{6}\right.$ and $\left.3.3 \times 10^{8} \mathrm{CFU} / \mathrm{g}\right)$. In the control feed, no lactic acid bacteria growth was observed.

The bacterial count in the tambaqui gut showed concentration of $B$. cereus at $2.4 \times 10^{2}, 3.0 \times 10^{4}$ and $2.7 \times 10^{6} \mathrm{CFU} / \mathrm{g}$ for the fish groups supplemented with $10^{4}, 10^{6}$ and $10^{8} \mathrm{CFU} / \mathrm{g}$ diet respectively.

Fish fed the probiotic-free diet showed higher concentrations of total heterotrophic bacteria in the gut $\left(3.6 \times 10^{6} \mathrm{CFU} / \mathrm{g}\right.$ gut $)$ as compared with fish fed probiotic-supplemented diet $\left(2.3 \times 10^{5}\right.$, $4.2 \times 10^{4}$ and $2.8 \times 10^{4} \mathrm{CFU} / \mathrm{g}$ gut, respectively) at concentrations of $10^{4}, 10^{6}$ and $10^{8} \mathrm{CFU} / \mathrm{g}$ diet.

\subsection{Challenge Assay}

In the challenge assay, nonchallenged unsupplemented fish (negative control) had $100 \%$ survival, which suggests no influence of external factors on the assay (Figure 1). However, fish from the positive control showed body darkening, ulcers at the point of inoculation, visceral swelling and anus dilatation according to degree 3 of Ray (1954) within $6 \mathrm{hr}$ postinfection. Mortality occurred between 41 and $56 \mathrm{hr}$ postinfection with the lowest survival rate of $33.4 \%$ observed in this group (Figure 1). Eight hours after infection, fish fed all supplemented diets showed degree 2 of body darkening (Ray, 1954) and resumed normal pigmentation $56 \mathrm{hr}$ after infection. Relative per cent survival was

TABLE 1 Growth performance, productivity and survival rate of tambaqui Colossoma macropomum juveniles fed diets supplemented with Bacillus cereus as probiotic bacteria for 120 days

\begin{tabular}{|c|c|c|c|c|c|c|c|c|c|}
\hline Treatment & TLG (mm) & SLG (mm) & $\mathrm{HL}(\mathrm{mm})$ & WG (g) & SGR (\%/day) & PRO $\left(\mathrm{kg} / \mathrm{m}^{3}\right)$ & S (\%) & FCR $(g / g)$ & K (\%) \\
\hline \multicolumn{10}{|l|}{30 days } \\
\hline Control & $18.1 \pm 3.1$ & $14.5 \pm 1.3$ & $9.0 \pm 1.4$ & $4.1 \pm 0.7$ & $5.2 \pm 0.2$ & $1.1 \pm 0.0$ & 100 & $1.8 \pm 0.1$ & $0.8 \pm 0.0$ \\
\hline $10^{4}(\mathrm{CFU} / \mathrm{g})$ & $18.6 \pm 2.4$ & $15.0 \pm 0.4$ & $9.6 \pm 1.6$ & $4.2 \pm 1.5$ & $5.2 \pm 0.6$ & $1.1 \pm 0.0$ & 100 & $1.7 \pm 0.1$ & $0.8 \pm 0.0$ \\
\hline $10^{6}$ (CFU/g) & $17.4 \pm 1.3$ & $14.9 \pm 1.2$ & $9.0 \pm 0.8$ & $4.6 \pm 1.3$ & $5.5 \pm 0.4$ & $1.1 \pm 0.0$ & 100 & $1.7 \pm 0.1$ & $0.8 \pm 0.0$ \\
\hline $10^{8}(\mathrm{CFU} / \mathrm{g})$ & $19.1 \pm 1.8$ & $15.3 \pm 1.0$ & $9.3 \pm 0.9$ & $4.2 \pm 1.5$ & $5.3 \pm 0.2$ & $1.8 \pm 0.0$ & 100 & $1.7 \pm 0.1$ & $0.8 \pm 0.0$ \\
\hline \multicolumn{10}{|l|}{60 days } \\
\hline Control & $39.7 \pm 0.7$ & $31.2 \pm 1.1$ & $15.4 \pm 0.8$ & $13.4 \pm 2.3^{\mathrm{b}}$ & $4.1 \pm 0.7$ & $3.7 \pm 0.0^{b}$ & 98 & $2.0 \pm 0.1$ & $1.2 \pm 0.1$ \\
\hline $10^{4}$ (CFU/g) & $40.6 \pm 1.2$ & $32.1 \pm 0.8$ & $15.1 \pm 1.1$ & $15.4 \pm 2.8^{a}$ & $4.4 \pm 0.7$ & $4.0 \pm 0.0^{a}$ & 100 & $1.9 \pm 0.0$ & $1.4 \pm 0.1$ \\
\hline $10^{6}(\mathrm{CFU} / \mathrm{g})$ & $42.2 \pm 0.8$ & $32.3 \pm 0.5$ & $14.9 \pm 1.1$ & $14.0 \pm 1.9^{\mathrm{a}}$ & $4.2 \pm 0.3$ & $4.0 \pm 0.2^{\mathrm{a}}$ & 99 & $1.9 \pm 0.1$ & $1.4 \pm 0.1$ \\
\hline $10^{8}$ (CFU/g) & $40.0 \pm 1.0$ & $31.6 \pm 1.1$ & $15.2 \pm 1.6$ & $14.9 \pm 2.7^{a}$ & $4.3 \pm 0.9$ & $3.8 \pm 0.1^{\mathrm{ab}}$ & 98 & $1.9 \pm 0.1$ & $1.5 \pm 0.0$ \\
\hline \multicolumn{10}{|l|}{90 days } \\
\hline Control & $28.4 \pm 1.3^{\mathrm{b}}$ & $19.9 \pm 1.2^{\mathrm{b}}$ & $9.0 \pm 1.4^{b}$ & $24.3 \pm 0.8^{b}$ & $3.3 \pm 0.7^{\mathrm{ab}}$ & $7.9 \pm 0.3^{b}$ & 98 & $1.9 \pm 0.1$ & $1.2 \pm 0.0$ \\
\hline $10^{4}$ (CFU/g) & $32.6 \pm 0.9^{\mathrm{ab}}$ & $21.5 \pm 0.9^{a b}$ & $11.4 \pm 1.3^{\mathrm{ab}}$ & $25.0 \pm 0.6^{a b}$ & $3.2 \pm 0.5^{b}$ & $8.3 \pm 0.2^{\mathrm{ab}}$ & 100 & $1.9 \pm 0.0$ & $1.3 \pm 0.0$ \\
\hline $10^{6}$ (CFU/g) & $32.7 \pm 1.5^{\mathrm{ab}}$ & $22.2 \pm 0.7^{\mathrm{ab}}$ & $12.3 \pm 1.5^{\mathrm{a}}$ & $28.2 \pm 1.9^{a}$ & $3.6 \pm 1.7^{\mathrm{a}}$ & $8.6 \pm 0.2^{a}$ & 99 & $1.9 \pm 0.1$ & $1.5 \pm 0.0$ \\
\hline $10^{8}(\mathrm{CFU} / \mathrm{g})$ & $36.5 \pm 0.9^{a}$ & $24.6 \pm 1.0^{a}$ & $13.6 \pm 1.5^{\mathrm{a}}$ & $29.5 \pm 0.6^{a}$ & $3.7 \pm 1.3^{a}$ & $8.7 \pm 0.3^{a}$ & 96 & $1.9 \pm 0.1$ & $1.3 \pm 0.0$ \\
\hline \multicolumn{10}{|l|}{120 days } \\
\hline Control & $38.2 \pm 1.9^{b}$ & $34.1 \pm 0.8^{b}$ & $11.7 \pm 0.4^{b}$ & $32.4 \pm 0.8^{b}$ & $2.0 \pm 0.3$ & $14.0 \pm 0.8^{b}$ & 98 & $1.9 \pm 1.1$ & $1.4 \pm 0.0$ \\
\hline $10^{4}$ (CFU/g) & $44.5 \pm 1.8^{a}$ & $35.4 \pm 1.1^{\mathrm{ab}}$ & $16.3 \pm 0.4^{a}$ & $37.2 \pm 0.7^{a}$ & $2.1 \pm 0.8$ & $15.8 \pm 0.5^{\mathrm{a}}$ & 100 & $1.9 \pm 1.3$ & $1.5 \pm 0.0$ \\
\hline $10^{6}(\mathrm{CFU} / \mathrm{g})$ & $43.5 \pm 1.0^{\mathrm{a}}$ & $37.2 \pm 0.9^{a}$ & $17.4 \pm 1.0^{\mathrm{a}}$ & $38.6 \pm 0.6^{a}$ & $2.1 \pm 0.6$ & $16.3 \pm 0.4^{a}$ & 99 & $1.9 \pm 2.0$ & $1.7 \pm 0.0$ \\
\hline $10^{8}(\mathrm{CFU} / \mathrm{g})$ & $44.2 \pm 1.0^{\mathrm{a}}$ & $38.1 \pm 0.5^{a}$ & $18.0 \pm 0.9^{a}$ & $38.3 \pm 0.8^{\mathrm{a}}$ & $2.0 \pm 0.9$ & $15.9 \pm 0.7^{a}$ & 96 & $1.9 \pm 1.6$ & $1.5 \pm 0.0$ \\
\hline
\end{tabular}

Note. FCR: feed conversion ratio; HL: height gain; K: Fulton's condition factor; PRO: productivity; TLG: total length gain; SGR: specific growth rate; S: survival; SLG: standard length gain; WG: weight gain. When present, distinct letters in each column indicate significant differences among treatments as determined by Tukey's test $(p<0.05)$. 
TAB LE 2 Haematological responses of juvenile Colossoma macropomum fed diets supplemented with Bacillus cereus as probiotic bacteria

\begin{tabular}{|c|c|c|c|c|}
\hline Parameters & Control & $10^{4} \mathrm{CFU} / \mathrm{g}$ & $10^{6} \mathrm{CFU} / \mathrm{g}$ & $10^{8} \mathrm{CFU} / \mathrm{g}$ \\
\hline Glucose (mg/dl) & $37.8 \pm 3.8^{b}$ & $48.4 \pm 3.5^{\mathrm{a}}$ & $41.8 \pm 4.2^{\mathrm{ab}}$ & $41.8 \pm 4.3^{\mathrm{ab}}$ \\
\hline Erythrocyte $\left(\times 10^{6} \mu \mathrm{l}^{-1}\right)$ & $1.2 \pm 0.8^{b}$ & $1.5 \pm 0.2^{\mathrm{a}}$ & $1.6 \pm 0.6^{a}$ & $1.5 \pm 0.2^{\mathrm{a}}$ \\
\hline Protein (g/dl) & $5.0 \pm 0.3^{b}$ & $5.0 \pm 0.3^{b}$ & $5.2 \pm 0.1^{\mathrm{ab}}$ & $5.4 \pm 0.1^{a}$ \\
\hline Haemoglobin (g/dl) & $9.1 \pm 0.8^{a}$ & $9.6 \pm 0.4^{a}$ & $9.7 \pm 0.9^{a}$ & $9.6 \pm 0.4^{a}$ \\
\hline $\mathrm{CHCM}(\mathrm{g} / \mathrm{dl})$ & $33.8 \pm 5.0^{\mathrm{a}}$ & $34.1 \pm 5.4^{\mathrm{a}}$ & $35.8 \pm 6.2^{\mathrm{a}}$ & $32.3 \pm 4.7^{\mathrm{a}}$ \\
\hline Thrombocytes $\left(\times 10^{3} \mu l^{-1}\right)$ & $35.5 \pm 8.5^{b}$ & $40.8 \pm 13.5^{b}$ & $60.8 \pm 10.7^{a}$ & $43.3 \pm 7.1^{\mathrm{b}}$ \\
\hline Leucocytes $\left(\times 10^{3} \mu \mathrm{I}^{-1}\right)$ & $34.6 \pm 16.7^{a}$ & $47.9 \pm 14.5^{a}$ & $53.5 \pm 15.1^{\mathrm{a}}$ & $51.6 \pm 19.1^{\mathrm{a}}$ \\
\hline Lymphocytes $\left(\times 10^{3} \mu \mathrm{I}^{-1}\right)$ & $28.8 \pm 17.0^{a}$ & $40.9 \pm 14.0^{\mathrm{a}}$ & $45.2 \pm 15.0^{\mathrm{a}}$ & $44.0 \pm 14.8^{\mathrm{a}}$ \\
\hline
\end{tabular}

Note. CHCM: mean corpuscular haemoglobin concentration; HCM: mean corpuscular haemoglobin; VCM: mean corpuscular volume. Distinct letters in the same row indicate significant differences after Tukey's test $(p<0.05)$.

higher $(p<0.05)$ in fish fed diets containing probiotic $(88.8 \%$, $80.5 \%$ and $80.5 \%$ respectively) relative to the control group (33.4\%) (Figure 1).

\section{4 | DISCUSSION}

The isolation and selection of specific beneficial bacteria from the intestinal tract of tambaqui constitutes an important strategy for the development of probiotics for this species (Ferreira et al., 2014). In this study, we found, for the first time, that the use of the autochthonous bacteria $B$. cereus improves the growth performance, productivity, haematological profile and survival of tambaqui juveniles.

Recent results involving the use of commercial probiotics in tambaqui feed are contradictory (Azevedo et al., 2016; Ferreira et al.,

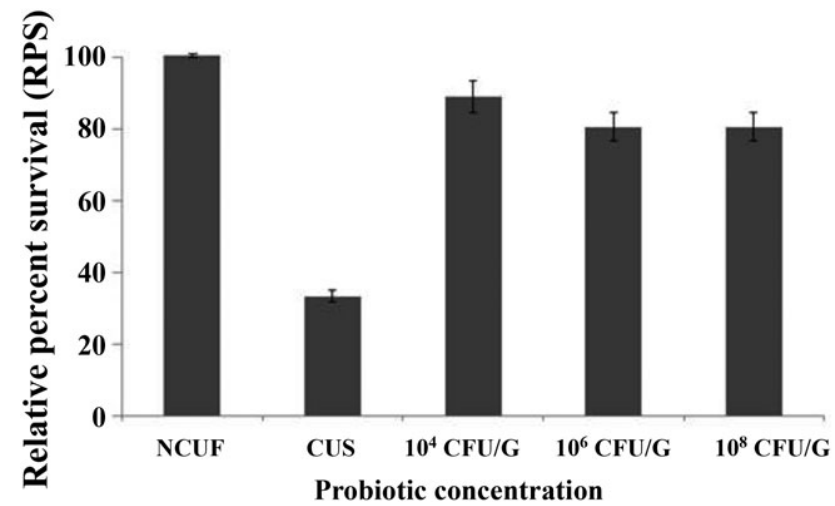

FIGURE 1 Mean values of relative per cent survival (RPS) in tambaqui Colossoma macropomum fed diets supplemented with Bacillus cereus (CFU/g) after challenge with Aeromonas hydrophila (CFU/g). NCUF and CUS correspond to nonchallenged unsupplemented fish and challenged unsupplemented fish respectively [Colour figure can be viewed at wileyonlinelibrary.com]
2014; Paixão et al., 2017). In all these studies, bacteria of the genus Bacillus were used as a dietary additive, usually involving a specific strain B. subtilis (Azevedo et al., 2016; Paixão et al., 2017) or a combination of Bacilli, B. licheniformis, B. subtilis and B. pumilus (Ferreira et al., 2014). According to Azevedo et al. (2016), dietary supplementation with probiotic $B$. subtilis in tambaqui improves growth performance and feed utilization after feeding for 56 days; however, Paixão et al. (2017), using the same commercial bacterial species, found no influence on growth performance of tambaqui after 90 days of feeding. Ferreira et al. (2014) used a commercial probiotic composed of a mixture of Bacilli (B. licheniformis, B. subtilis and $B$. pumilus) and investigated its effects after feeding tambaqui for 60 days; these authors did not observe any significant changes in intestinal weight, or height and length of intestinal villi.

According to these authors, the host-probiotic relationship appears to be species-specific, and it is possible that the Bacillus strain or the concentration used in the commercial product were not suitable for tambaqui.

Several factors are responsible for the inconsistent effects reported in the literature, including the origin and source of probiotics, dose and duration of supplementation, method of probiotic application, fish species and bacteria strain, fish size and age, water quality parameters, stocking density, nutritional and feeding regime factors, and type of rearing system used (Doan, Hoseinifar, Dawood, Chitmanat, \& Tayyamath, 2017; Doan, Hoseinifar, Tapingkae, Tongsiri, \& Khamtavee, 2016; Ridha \& Azad, 2016).

Factors such as dose and duration of autochthonous probiotic feeding had a direct influence on the results of the present study. The onset of the beneficial effects of probiotics on performance (weight gain and productivity) was observed only after 60 days of supplementation at higher concentrations, i.e. $10^{6}$ and $10^{8} \mathrm{CFU} / \mathrm{g}$ diet. Furthermore, after 90-120 days, improvements in total and 
standard length gain, height gain and specific growth rate were also attained at these higher concentrations. This enhanced growth performance of fish supplemented with probiotics is probably due to an improvement in digestion as well as an increase in the synthesis and absorption of nutrients (Hoseinifar, Dadar, \& Ringo, 2017). Similar results were obtained by El-Haroun, Goda, and Chowdhury (2006) reporting increased growth performance and feed efficiency in tilapia fed the probiotics Bacillus licheniformis and Bacillus subtilis. According to these authors, the added probiotics improved digestibility, dietary protein and energy utilization. These positive effects can be attributed to the capacity of the probiotics to promote an increase in the gut absorbent surface area, and stimulate and/or produce several enzymes on the intestinal tract, which improve digestibility and nutrient retention, leading to higher growth rates (El-Haroun et al., 2006; Ibrahem, 2015; Mello et al., 2013).

In addition to improving performance, a beneficial effect of the probiotic supplementation on haematological parameters was also observed in juvenile tambaqui. Haematological parameters are commonly used as indicators of the physiological condition in fish, as they reflect the health state of the farmed fish (Akter, Parvez, \& Patwary, 2016; Silva \& Fujimoto, 2015). In the present study, no differences in haemoglobin levels, haematological indices (VCM, HCM and CHCM), leucocytes, lymphocytes, monocytes or basophils were observed. However, increased glucose levels, total plasma protein, haematocrit, erythrocytes, thrombocytes and neutrophils were observed.

Blood glucose in tambaqui was significantly affected by the dietary intake of probiotics. This parameter can be used as an indicator of energy metabolism (González, 1997). Increased blood glucose may have been stimulated in response to increased availability and absorption of nutrients from the feed, interfering with the glycaemic metabolism. Supplementation with probiotics is associated with microbial changes in the gut which modulate the expression of a complex network of genes that affect glucose metabolism (Falcinelli et al., 2016). Changes in the intestinal microbiota observed in tambaqui as a result of probiotic inclusion in the diet may have modulated the expression of genes involved in glucose metabolism, resulting in increased glycaemia. Further studies are needed to determine the exact mechanisms by which $B$. cereus influences glucose metabolism of the host.

Total plasma protein concentration and haematocrit values were significantly altered by the inclusion of $B$. cereus in tambaqui diet. The increase in plasma protein concentration is primarily due to the albumin and globulin fractions, which are responsible for the transport of nutrients, maintenance of blood osmotic balance and improvement of animal defence mechanisms (Thomas, 2000). The increase in haematocrit values after feeding with probiotics reflects the safe use of these additives and their efficacy for improving health status (Aly, Ahmed, Aziz, \& Mohamed, 2008). In the present study, both the elevated plasma protein level and the increased haematocrit values demonstrate the good nutritional and sanitary status of the fish supplemented with $B$. cereus. Similar results were observed in tilapia supplemented with probiotic Saccharomyces cerevisiae (Abdel-Tawwab, Abdel-Rahman, \& Ismael, 2008), Bacillus subtilis, and Lactobacillus acidophilus (Aly et al., 2008).

The progressive increase in the concentration of $B$. cereus stimulated a linear increase in the number of neutrophils. Neutrophils are cells involved in the innate cellular response and are the first cells that migrate to an inflammatory site (Yamashita et al., 2017). The increase in the number of these cells in tambaqui blood indicates an immunostimulating effect of $B$. cereus, where the highest concentration of host defence cells depends on the amount of probiotic bacteria provided in the diet.

In the present study, an increase in thrombocyte concentrations in fish supplemented with $10^{6} \mathrm{CFU} / \mathrm{g} \mathrm{B}$. cereus was also observed. The innate cellular immune system is formed by a series of cells which are vital to the survival of the host, among these cells, thrombocytes act on the animal's defence mechanism, participating in coagulation and in cellular phagocytic processes (Gómez \& Balcázar, 2007; Nakandakare et al., 2013).

Therefore, the probiotic promoted a nonspecific response against bacterial infection, increasing fish survival after challenge with $A$ hydrophila. The probiotic supplementation increases the phagocytic activity of neutrophils as verified in Sparus aurata $(65 \mathrm{~g})$, Oncorhynchus mykiss (30 g) and Larimichthys crocea (7 g) fed Lactobacillus delbrueckii and B. subtilis, commercial $B$. subtilis and $B$. subtilis, respectively (Ai et al., 2011; Newaj-Fyzul et al., 2007; Salinas, Cuesta, Esteban, \& Meseguer, 2005).

In conclusion, dietary supplementation with the autochthonous probiotic $B$. cereus altered the intestinal microbiota of tambaqui $C$. macropomum, improved the immune system-related haematological parameters, and enhanced growth performance and survival in this species. Supplementation with probiotics can be provided at the concentration of $10^{6} \mathrm{CFU} / \mathrm{g}$ diet, and fish should be fed for at least 60 days.

\section{ACKNOWLEDGMENTS}

The authors thank the National Council of Scientific and Technological Development - CNPq - Brazil for the financial support (432622/ 2016-0) and grants provided to R.Y. Fujimoto (305195/2016-6) and M.L. Martins (CNPq 305869/2014-0).

\section{ORCID}

Joel A R Dias iD http://orcid.org/0000-0001-9751-0207

Higo A Abe (iD http://orcid.org/0000-0002-5717-9641

Fernanda S Cunha (D) http://orcid.org/0000-0003-2883-7542

Mauricio L Martins (iD http://orcid.org/0000-0002-0862-6927

\section{REFERENCES}

Abdel-Tawwab, M., Abdel-Rahman, A. M., \& Ismael, N. E. M. (2008). Evaluation of commercial live bakers' yeast, Saccharomyces cerevisiae as a growth and immunity promoter for fry Nile tilapia, Oreochromis niloticus (L.) challenged in situ with Aeromonas hydrophila. 
Aquaculture, 280, 185-189. https://doi.org/10.1016/j.aquaculture. 2008.03.055.

Ai, Q., Xu, H., Mai, K., Xu, W., Wang, J., \& Zhang, W. (2011). Effects of dietary supplementation of Bacillus subtilis and fructooligosaccharide on growth performance, survival, non-specific immune response and disease resistance of juvenile large yellow croaker, Larimichthys crocea. Aquaculture, 317, 155-161. https://doi.org/10.1016/j.aquacul ture.2011.04.036.

Akter, M. N., Parvez, I., \& Patwary, Z. P. (2016). Beneficial effects of probiotics in aquaculture. International Journal of Fisheries Aquatic Studies, 4(5), 494-499.

Aly, S. M., Ahmed, Y. A., Aziz, A. A. G., \& MohamedM. F. (2008). Studies on Bacillus subtilis and Lactobacillus acidophilus, as potential probiotics, on the immune response and resistance of Tilapia nilotica (Oreochromis niloticus) to challenge infections. Fish \& Shellfish Immunology, 25, 128-136. https://doi.org/10.1016/j.fsi.2008.03.013.

Araújo, E. R. L., Barbas, L. A. L., Ishikawa, C. M., Dias, D. C., Sussel, F. R., Marques, H. L. A., \& Tachibana, L. (2017). Prebiotic, probiotic, and synbiotic in the diet of Nile tilapia post-larvae during the sex reversal phase. Aquaculture International, 26, 1-13. https://doi.org/10.1007/ s10499-017-0201-7.

Azevedo, R. V., Fosse Filho, J. C., Pereira, S. L., Cardoso, L. D., Vidal Júnior, M. V., \& Andrade, D. R. (2016). Suplementação com prebiótico, probiótico e simbiótico para juvenis de tambaqui a duas densidades de estocagem. Pesquisa Agropecuária Brasileira, 51(1), 9-16. https://doi.org/10.1590/S0100-204X2016000100002.

Doan, H. V., Hoseinifar, S. H., Dawood, M. A. O., Chitmanat, C., \& Tayyamath, K. (2017). Effects of Cordyceps militaris spent mushroom substrate and Lactobacillus plantarum on mucosal, serum immunology and growth performance of Nile tilapia (Oreochromis niloticus). Fish \& Shellfish Immunology, 70, 87-94. https://doi.org/10.1016/j.fsi.2017. 09.002 .

Doan, H. V., Hoseinifar, S. H., Khanongnuch, C., Kanpiengjai, A., Unban, K., Kim, V. V., \& Srichaiyo, S. (2018). Host-associated probiotics boosted mucosal and serum immunity, disease resistance and growth performance of Nile tilapia (Oreochromis niloticus). Aquaculture, 491, 94-100. https://doi.org/10.1016/j.aquaculture.2018.03.019.

Doan, V. H., Hoseinifar, S. H., Tapingkae, W., Tongsiri, S., \& Khamtavee, P. (2016). Combined administration of low molecular weight sodium alginate boosted immunomodulatory, disease resistance and growth enhancing effects of Lactobacillus plantarum in Nile tilapia (Oreochromis niloticus). Fish \& Shellfish Immunology, 58, 678-685. https://d oi.org/10.1016/j.fsi.2016.10.013.

El-Haroun, E. R., Goda, A. S., \& Chowdhury, K. (2006). Effect of dietary probiotic Biogen ${ }^{\circledR}$ supplementation as a growth promoter on growth performance and feed utilization of Nile tilapia Oreochromis niloticus (L.). Aquaculture Research, 37(14), 1473-1480. https://doi.org/10. 1111/j.1365-2109.2006.01584.x.

Falcinelli, S., Rodiles, A., Unniappan, S., Picchietti, S., Gioacchini, G., Merrifield, D. L., \& Carnevali, O. (2016). Probiotic treatment reduces appetite and glucose level in zebrafish model. Scientific Reports, 6, 18061. https://doi.org/10.1038/srep18061.

Ferreira, C. M., Antoniassi, N. A. B., Silva, F. G., Povh, J. A., Potença, A., Moraes, T. C. H., ... Abreu, J. S. (2014). Características histomorfométricas do intestino de juvenis de tambaqui após uso de probiótico na dieta e durante transporte. Pesquisa Veterinária Brasileira, 34 1258-1264. https://doi.org/10.1590/S0100-736X2014001200020.

Fontes, D. G., Monteiro, M. V. B., Jorge, E. M., Oliveira, C. M. C., Ritter, R. A., Neto, J. D. B., ... Monteiro, F. O. B. (2014). Perfil hematológico e bioquímico de búfalos (Bubalus bubalis) na Amazônia Oriental. Pesquisa Veterinária Brasileira, 34, 57-63. https://doi.org/10.1590/ S0100-736X2014001300011.

Gatesoupe, F. J. (1999). The use of probiotics in aquaculture. Aquaculture, 180, 147-165. https://doi.org/10.1016/S0044-8486(99)00187-8.
Goldenfarb, P. B., Bowyer, F. P., Hall, E., \& Brosius, E. (1971). Reproductibility in the hematology laboratory: The microhematocrit determination. American Journal of Clinical Pathology, 56, 35-39. https://d oi.org/10.1093/ajcp/56.1.35.

Gómez, G. D., \& Balcázar, J. L. (2007). A review on the interactions between gut microbiota and innate immunity of fish. FEMS Immunology \& Medical Microbiology, 52(2), 145-154. https://doi.org/10.1111/ j.1574-695X.2007.00343.x.

González, F. H. D. (1997). O perfil metabólico no estudo de doenças da produção em vacas leiteiras. Arquivo Da Faculdade De Veterinária Da UFRGS, 25, 13-33.

Hoseinifar, S. H., Dadar, M., \& Ringo, E. (2017). Modulation of nutrient digestibility and digestive enzyme activities in aquatic animals: The functional feed additives scenario. Aquaculture Research, 48, 39874000. https://doi.org/10.1111/are.13368.

Hoseinifar, S. H., Sun, Y. Z., \& Caipang, M. C. (2016). Short-chain fatty acids as feed supplements for sustainable aquaculture: An updated view. AquacultureResearch, 48(4), 1380-1391. https://doi.org/10. 1111/are.13239.

Ibrahem, M. D. (2015). Evolution of probiotics in aquatic world: Potential effects, the current status in Egypt and recent prospectives. Journal of Advanced Research, 6, 765-791. https://doi.org/10.1016/j.jare. 2013.12.004.

Jatobá, A., \& Mouriño, J. L. P. (2015). Efeito do Lactobacillus plantarum no trato intestinal de alevinos de Oreochromis niloticus. Ciência Animal Brasileira, 16, 45-53. https://doi.org/10.1590/1089-68916i127789.

Jatobá, A., Vieira, F. D., Neto, C. B., Silva, B. C., Mourino, J. L. P., Jeronimo, G. T., ... Martins, M. L. (2008). Lactic-acid bactéria isolated from the intestinal tract of Nile tilapia utilized as probiotic. Pesquisa Agropecuaria Brasileira, 43, 1201-1207. https://doi.org/10.1590/S0100204X2008000900015

Jin, J. D. (2006). Molecular Typing Random Amplification of Polymorphic DNA (RAPD) and Detection of Virulence Genes of Salmonella enterica serovar Gallinarum biovar gallinarum. The Japanese Society of Veterinary Science, 68, 1321-1326. https://doi.org/10.1292/jvms.68. 1321.

Kamper, E. J., \& Zijlstra, W. G. (1961). Standardization of hemoglobinometry. II. The hemoglobin cyanide method. Clinica Chimica Acta, 6, 538-544. https://doi.org/10.1016/0009-8981(61)90145-0.

Madani, N. S. H., Adorian, T. J., Farsani, H. G., \& Hoseinifar, S. H. (2018). The effects of dietary probiotic Bacilli (Bacillus subtilis and Bacillus licheniformis) on growth performance, feed efficiency, body composition and immune parameters of whiteleg shrimp (Litopenaeus vannamei) postlarvae. Aquaculture Research, 00, 1-8. https://doi.org/10. 1111/are.13648

Mello, H., Moraes, J. R. E., Niza, I. G., Moraes, F. R., Ozório, R. O. A., Shimada, M. T., ... Claudiano, G. S. (2013). Efeitos benéficos de probióticos no intestino de juvenis de Tilápia-do-Nilo. Pesquisa Veterinária Brasileira., 33, 724-730. https://doi.org/10.1590/S0100736X2013000600006.

Morais, I. S., \& O'Sullivan, F. L. A. (2017). Biologia, habitat e cultivo do tambaqui Colossoma macropomum (Cuvier, 1816). Scientia Amazonia, 6 (1), 81-93.

Nakandakare, I. B., Iwashita, M. K. P., Dias, D. C., Tachibana, L., RanzaniPaiva, M. J. T., \& Romagosa, E. (2013). Incorporação de probióticos na dieta para juvenis de tilápias-do-Nilo: parâmetros hematológicos, imunológicos e microbiológicos. Boletim do Instituto De Pesca, 39, 121-135.

Naser, S. M., Dawyndt, P., Hoste, B., Gevers, D., Vandemeulebroecke, K., Cleenwerck, I., ... Swings, J. (2007). Identification of lactobacilli by pheS and rpoA gene sequence analyses. International Journal of Systematic and Evolutionary Microbiology, 57, 2777-2789. https://doi. org/10.1099/ijs.0.64711-0.

Nawaz, A., Javaid, A. B., Irshad, S., Hoseinifar, S. H., \& Xiong, H. (2018). The functionality of prebiotics as immunostimulant: Evidences from 
trials on terrestrial and aquatic animals. Fish \& Shellfish Immunology, 76, 272-278. https://doi.org/10.1016/j.fsi.2018.03.004.

Newaj-Fyzul, A., Adesiyun, A. A., Mutani, A., Ramsubhag, A., Brunt, J., \& Austin, B. (2007). Bacillus subtilis AB1 controls Aeromonas infection in rainbow trout (Oncorhynchus mykiss, Walbaum). Journal of Applied Microbiology, 103, 1699-1706. https://doi.org/10.1111/j.1365-2672. 2007.03402.x

Paixão, A. E. M., Santos, J. C., Pinto, M. S., Pereira, D. S. P., Ramos, C. E. C. O., Cerqueira, R. B., ... Silva, R. F. (2017). Effect of commercial probiotics (Bacillus subtilis and Saccharomyces cerevisiae) on growth performance, body composition, hematology parameters, and disease resistance against Streptococcus agalactiae in tambaqui (Colossoma macropomum). Aquaculture International, 1-11, https://doi.org/10. 1007/s10499-017-0173-7.

Pavanelli, G. C., Eiras, J. C., \& Takemoto, R. M. (2002). Doenças De peixes: Profilaxia, diagnóstico e tratamento (p. 331). Maringá: Eduem.

Ramirez, C., Cifonni, E. M. G., Pancheniak, E. F. R., \& Soccol, C. R. (2006). Microrganismo láctico com características probióticas para ser aplicados em la alimentación de larvas de camarón y peces como substituto de antibiótico. La Alimentacion Latinoamericana, 264, 70-78.

Ray, S. M. (1954). Biological studies of Dermocystidium marinum, a fungus parasite of oysters. Doctoral Thesis in Natural Sciences. (p. 120). Houston, TX: Rice Institute.

Ricker, W. E. (1975). Computation and interpretation of biological statistics of fish populations, 191 ed. (pp. 382). Canadá: Bulletin of the Fisheries Research Board of Canada.

Ridha, M. T., \& Azad, I. S. (2016). Effect of autochthonous and commercial probiotic bacteria on growth, persistence, immunity and disease resistance in juvenile and adult Nile tilapia Oreochromis niloticus. Aquaculture Research, 47, 2757-2767. https://doi.org/10.1111/are.12726.

Sales, R. O., \& Maia, E. L. (2013). Composição química e classes de lipídios em peixe de água doce tambaqui, Colossoma macropomum. Revista Brasileira De Higiene E Sanidade Animal, 7(2), 31-44. https://d oi.org/10.5935/1981-2965.20130009.

Salinas, I., Cuesta, A., Esteban, M. A., \& Meseguer, J. (2005). Dietary administration of Lactobacillus delbrueckii and Bacillus subtilis, single or combined, on gilthead seabream cellular innate immune responses. Fish \& Shellfish Immunology, 19, 67-77. https://doi.org/10.1016/j.fsi. 2004.11.007.
Sambrook, J., Fritsch, E. F., \& Maniatis, T. (1989). Molecular cloning: A laboratory manual, 2 ed (p. 1546). Cold Spring Harbor, TX: Cold Spring Harbor Laboratory Press, University of Texas South Western Medical Center.

Sambrook, J., \& Russell, D. W. (2001). Molecular cloning: A laboratory manual (p. 2344). New York, NY: Cold Spring Harbor Laboratory Press.

Silva, C. A., \& Fujimoto, R. Y. (2015). Crescimento de tambaqui em resposta a densidade de estocagem em tanques-rede. Acta Amazonica, 45, 323-332. https://doi.org/10.1590/1809-4392201402205.

Tavares-Dias, M., \& Moraes, R. F. (2004). Hematologia de Peixes Teleósteos. (p. 144) São Paulo, SP: Ribeirão Preto.

Tavares-Dias, M., \& Moraes, F. R. (2006). Hematological parameters for the Brycon orbignyanus Valenciennes, 1850 (Osteichthyes, Characidae) intensively bred. Hidrobiologica., 16(3), 271-274.

Thomas, J. S. (2000). Overview of plasma proteins. In: B. F. Feldman (eds) Schalm's veterinary hematology (pp. 891-898), Philadelphia, PA: Lippincott.

Vallada, E. P. (1999). Manual de Técnicas Hematológicas. (pp. 2-104). São Paulo, SP: Editora Atheneu.

Wang, Y. B., Tian, Z. Q., Yao, J. T., \& Li, W. F. (2008). Effect of probiotics, Enteroccus faecium, on tilapia (Oreochromis niloticus) growth performance and immune response. Aquaculture, 277, 203-207. https://doi. org/10.1016/j.aquaculture.2008.03.007.

Yamashita, M. M., Pereira, S. A., Cardoso, L., Araujo, A. P., Oda, C. E., Schmidt, É. C., ... Mouriño, J. L. P. (2017). Probiotic dietary supplementation in Nile tilapia as prophylaxis against streptococcosis. Aquaculture Nutrition, 00, 1-9. https://doi.org/10.1111/anu.12498.

How to cite this article: Dias JAR, Abe HA, Sousa NC, et al. Dietary supplementation with autochthonous Bacillus cereus improves growth performance and survival in tambaqui Colossoma macropomum. Aquac Res. 2018;49:3063-3070. https://doi.org/10.1111/are.13767 